\title{
Risk Determinant of Musharakah Financing: A Study in Indonesia
}

\author{
Rosmini Ramli*,1, Erie Febrian $^{2}$, Dian Masyita ${ }^{2}$, Mokhamad Anwar ${ }^{2}$ \\ ${ }^{1}$ Universitas Padjadjaran - Bandung, Universitas Indonesia Timur \\ ${ }^{2}$ Universitas Padjadjaran - Bandung
}

\section{ARTICLE INFO}

\section{Article history:}

Received 20 July 2019

Revised 23 September 2019 \& 01

January 2020

Accepted 17 February 2019

Published 31 March 2020

\section{Keywords:}

Financing risk

Musharakah contract

Risky sector

Internal and external factors

\begin{abstract}
The purpose of this paper is to find out the influence of internal and external factors on the risk of musharakah financing of Islamic Commercial Banks in Indonesia. Financing risks in previous Islamic banking studies focus more on overall financing risks involving internal and external aspects, both separately and jointly. There have been no studies that examine the internal and external aspects of sharia commercial banks on financing risks, especially in the musharakah contract. This study will complement the literature on the aforementioned issue. This study uses a quantitative method with panel data regression analysis. The data used is quarter financial ratio data from all Sharia Commercial Banks in Indonesia for the period 20122017. The results of the study show that bank internal factors predominantly influence the risk of musharakah financing. Whereas on external factors, only GDP growth has a significant effect.
\end{abstract}

\section{Introduction}

Islamic banking plays a role in providing financial services without usury to the public. Distribution of financing to the community both individually and in groups is not risk free, so that it requires efficient management, right on target and in accordance with sharia principles. Quality financing, which is reflected in the low level of Non Performing Financing (NPF), is a major supporter of the sustainability of Islamic banking operations because most Islamic bank assets are channeled in the form of financing.

High levels of problematic financing can be a source of disaster for banks (Waemustafa \& Sukri, 2015) and are also used to mark the occurrence of a banking crisis (Reinhart and Rogoff, 2010).

Credit risk causes more than three quarters of Islamic bank failures and one of the main risks that seriously affects the viability of banks as evidence of the 1997 financial crisis (Ali dan Ghauri (2013). Likewise, Fleifel (2009) and Ascarya (2009) assume that of the four main types of risks that cause systemic bank failures, credit risk is the most important risk. Credit risk appears to be more risk, especially with PLS financing modes (Chapra and Khan, 2000). The specific risks inherent in PLS financing, namely credit risk mitigation cannot be done by demanding collateral from borrowers, banks also do not have adequate control over financial project management (Errico and Farahbakhsh (1998).

Furthermore, other constraints such as moral hazard, law and high return volatility (Hart and Moore, 1998: 12; Rajesh and Aggarwal, 2000: 188) as well as profit sharing ratio or loss policy on each project can be complicated because of difficulties in measuring client characteristics and proposed business opportunities. This condition allows banks to obtain a low level of profit sharing, so banks need a lot of consideration in applying PLS for reasons of prudent attitudes.

The Islamic banks tend to apply the principles of non-PLS because of the risks and complexities associated with the PLS scheme (Abedifar et al., 2013). Revenue sharing schemes are considered more equitable because profits and

* Corresponding author.

E-Mail address: ramlirosmini17@gmail.com 
losses are shared between the bank and the customer according to the proportion of their respective capital, so that when the business being financed gains or losses, both parties are involved. In mudharabah profit sharing, the risk is borne by the capital owner, except if the loss is due to negligence of the capital manager (mudharib) and the profit sharing ratio is agreed upon at the beginning of the contract.

Generally, the risks inherent in PLS schemes include, among others, the potential use of funds outside the agreed contract (side streaming), intentional negligence or mistakes, as well as dishonest reporting on profits by partners (Antonio, 2001: 94). Other forms of risk include a lack of understanding and quality of human resources (bank staff), lack of supporting regulations (Ascarya, 2006), and difficulties in determining the appropriate profit sharing ratio at the beginning of a contract can make revenue sharing inefficient (Stiglitz, 1974).

In general, financing risks have been reviewed previously using internal and external factors, particularly in terms of the financing structure (Rahman and Shahimi, 2010; Misman, 2012), ownership structure (Srairi, 2013), and financing risks in general (Abedifar, et al. , 2013; Kabir, et al., 2015). Furthermore, Azmat, et al., (2014); Ramasamy, et al., (2011) also tested the risk of Islamic banks in the context of sukuk financing. Most studies find that risk is influenced by internal factors (eg, financing in high risk sectors and the level of management efficiency), and external factors (eg, GDP growth and inflation) (Al-Wesabi and Ahmad, 2013; Waemustafa and Sukri, 2015; Ahmad and Ahmad, 2004).

Other studies have found that revenue sharing in the form of musharakah has a higher risk compared to other contracts (Khan and Ahmed, 2001; Warninda, et al., 2019). However, their results do not report the level of risk in the musharakah contract, so it requires a deeper study to uncover the causes of the high risk of the contract. Musharakah financing is the biggest contributor to the increasing number of problematic financing of Islamic banks in Indonesia (Bank Indonesia, 2016). Therefore, this study provides an appropriate contribution in the study of the risk of channeling Islamic bank funds, by answering several issues.

The first issue, whether internal bank factors, such as return (Zribi and Boujelbene, 2011; Srairi, 2013; Kabir et al, 2015), capital regulation (Ahmad and Ahmad, 2004; Rahman and Shahimi, 2010), the portion of musharakah / PLS financing (Abusharbeh, 2014), the risk sector (Al-Wesabi and Ahmad, 2013; Waemustafa and Sukri, 2015), influence the risk level of musharakah financing as they influence the risk of Islamic banks as a whole?

The next issue is whether the macroeconomic conditions (external factors of the bank), such as inflation and GDP growth (Farook et al, 2014; Al-Wesabi and Ahmad, 2013), affect the risk of musharakah financing as they affect the risk of the whole contracts of Islamic bank? We find that internal factors, namely return, portion of musharakah, total financing and financing in the risk sector, significantly influence the risk of musharakah financing. This finding is relatively similar to the finding of Salas and Saurina (2002) in conventional banks which argue that internal bank variables are an early warning indicator of credit risk in Spain.

This study only focuses on the Musharakah which is the core scheme of Islamic bank operation for two reasons. Firstly, the Musharakah contract in Indonesian ICBs is a contract that has a higher risk than the Mudharabah contract. This is confirmed by the findings of Khan \& Ahmed (2001), dan Warninda et al (2019). Secondly, musharakah is one of the Profit Loss Sharing (PLS) schemes that is run more by Islamic banks than Mudharabah. Therefore, the study of the musharakah is urgent to help the industry manage the risk of financing in the future.

This paper will be arranged as follows. In section 2 is a review of the literature relating to determinants of financing risk. Section 3 presents the hypothesis to be tested. Section 4 provides a research method that will be used to answer the research hypothesis. Section 5 discusses the results of the study, and finally section 6 provides conclusions from the results of the study.

\section{Literature review}

\section{Financing Risk}

The risk of financing / credit is one of the main risks that seriously affects the viability of banks as evidence of the financial crisis that occurred in 1997 (Ali and Ghauri, 2013). Credit risk is the main source of financial instability in the banking sector (Bank for International Settlement, 2000). In sharia banking, the musharakah contract is one of the financing schemes for profit-loss sharing (PLS), where the financing scheme is considered more vulnerable to high risk than other financing schemes. The highest risk is found in the musharakah contract followed by mudharabah (Khan and Ahmed, 2001), so that the risk of Islamic bank financing cannot be separated from PLS-based financing which has a positive relationship (Abusharbeh, 2014). 
The financing that is supported by resource capacity, capital regulation, and continuous monitoring can reduce the level of risky financing problems (Louzis et al., 2012). This requires an investigation of the factors that influence the emergence of financing risks to ensure the growth and viability of the banking system.

This section aims to investigate the determinants that affect the risk of financial misuse both internally and externally from the bank. As stated by Ascharya (2006), the causes of credit risk can be derived from internal and external factors of the bank. From the internal side of the bank, these are the forms of macroeconomic conditions (Louzis, et al., 2011; Waemustafa and Sukri, 2015).

From the internal side of the bank, these factors can be in the form of management activities in managing productive assets, capital regulations, and lending policies, the rest are related to bank external conditions or macroeconomic conditions such as economic growth and inflation (Waemustafa and Sukri, 2015; Al-Wesabi and Ahmad, 2013).

\section{Bank Internal Factor}

Some empirical literature attempts to analyze the risk determinants of Islamic and conventional banking financing. Banks are more susceptible to exposure to problematic financing risks from internal factors in France (Chaibi, Hasna, and Ftiti, 2015). Similarly in other countries internal bank factors can be used as a tool to detect changes in the level of financing risks (Salas and Saurina, 2002).

A number of studies have discussed credit risk with the level of profitability in conventional banks and they found different results. Athanasoglou et al. (2008) found that credit risk as measured by the provision of loan loss ratio to total loans correlated negatively with bank profitability in a sample of banks in Greece. An increase in bad credit as a result of an increase in bank loan supply at risky schemes will result in a decline in returns. A negative relationship was also found by Apergis (2014) in a sample of banks in the United States.

The same coefficient is also shown by Dietrich and Wanzenried (2011) but is not significant for the sample of banks in Switzerland. Furthermore, the rate of return of assets channeled has a relationship with financing risks (Zribi and Boujelbene, 2011). The results show a positive and significant relationship with bank credit risk in the period 1995-2008 in Tunisia. This indicates that the most profitable banks are banks that have a higher risk. An important question that arises from the findings shown so far is whether variations in bad credit will increase or decrease the profitability of banks.

Waemustafa and Sukri (2015) examined the determinants of bank credit risk in Malaysia over the period 20002010 and found internal factors such as risk sector financing (RSF) and capital regulations (Regcap). Risk sector financing has a significant positive effect on the risk of financing Islamic banks. The ratio of risk assets to total assets is higher in Islamic banks than in conventional banks (Al-Wesabi and Ahmad, 2013). Islamic banking requires a careful attitude in handling risky portfolio financing (Ahmad and Ahmad, 2004; Ahmed, et al., 2011). Berger and DeYoung (1997) found risky loan portfolios tend to produce higher NPL ratios. This finding shows that the average bank serves credit that is more risky and has the potential to increase the NPL.

In addition, the capital regulation (Regcap) also contributes to the level of problematic financing of Islamic banks in Malaysia, and its influence is strong (Waemustafa and Sukri, 2015). Consistent with the findings of Ahmad and Ahmad, 2004; Rahman and Shahimi, 2010; Misman, 2012). However, it is different from the study by Zribi and Boujelbene (2011) who found a negative relationship between capital regulation and credit risk. This negative relationship indicates the regulation of effective capital can reduce bank risk. Compliance with the application of capital regulations stipulated by Bank Indonesia can help bank problems in facing financing risks that are likely to arise.

The Abusharbeh study (2014) uses the PLS scheme as a variable to reveal the risk of Islamic banks and the results have a significant effect. Therefore, the use of the variable amount of musharakah financing is based on previous empirical findings (Abusharbeh, 2014); Khan and Ahmed, 2001; Warninda, et al., 2019).

Likewise, total financing tends to have a high chance of problematic risk if it is not accompanied by caution (Misra and Dhal, 2010). Banks with large amounts of financing have the possibility to generate greater profits if followed by the results of their activities. The study conducted by Farook, Hasan, and Clinch (2014) and Misman (2012) states that an increase in total financing is associated with a decrease in the level of problematic financing. This means that the increase in total financing does not always lead to an increase in financing risk, if funding activities are accompanied by appropriate management and financing policies. This finding was supported by Wu, Chang and Selvili (2003) who found that total financing was negatively related to credit risk. 


\section{Bank External Factor}

Funding risk is not only influenced by internal factors, but also external factors (Louzis et al., 2011; Waemustafa and Sukri, 2015). Several studies discuss financing risks from the country's economic conditions such as GDP growth and inflation rates (Chaibi, Hasna and Ftiti, 2015; Yudakul, 2014; Abid, Quertani and Ghorbel, 2013; Castro, 2013; Nkuzu, 2011).

According to Bank Indonesia (2014), inflation is a reflection of an increase in prices in general and continuously. Influence of inflation rates that tend to shrink can increase the risk of Islamic and conventional bank financing in Malaysia (Waemustafa and Sukri, 2015). High inflation can cause people's purchasing power to decline and cause the inability of customers to pay their obligations. Waemustafa and Sukri, (2015) found a negative effect of inflation on the risk of Islamic bank financing, and an increase in inflation would exacerbate the amount of problem financing (Baboucek and Jancar, 2005).

In addition, a country's economic growth (GDP) also affects the risk of financing Islamic banks at a significance level of 5\% (Al-Wesabi and Ahmad, 2013). They describe the risk of financing decreasing when GDP increases. Different findings of Waemustafa and Sukri (2015) which state that GDP growth does not have a significant relationship with the risk of financing Islamic banks during the period 20002010 in Malaysia.

In general, the theory shows that when the GDP growth rate increases it will increase economic activity (Samuelson, 2001). Smooth credit payments are also influenced by the level of income of the community. The higher the level of income of the people reflected in GDP, the likelihood of bad loans getting smaller. Empirically, some authors found a negative impact between GDP growth and NPL (Khemraj \& Pasha, 2016; Atanasijevic and Bozovic, 2016; Irina \& Angela, 2016).

\section{Hypotheses}

The main objective of this test is to identify internal and external variables of the bank as factors that influence the risk of musharakah financing. Some previous literature informs that these variables have a significant impact on financing risk (Waemustafa and Sukri, 2015; Al-Wesabi and Ahmad; Srairi, 2013; Rahman and Shahimi; Al-Smadi 2010). We propose a number of hypotheses developed to see these influences on the risk of musharakah financing as described in the following questions.

Hypothesis 1 The yield of musharakah has a positive effect on NPF musharakah.

Musharakah yield is the first test on financing risk. The return on musharakah / ROM ratio is the development of the level of profitability proxied by ROA (net income / total assets) or ROE (net income / total equity). The Zribi and Boujelbene (2011) empirical study of the rate of return of assets channeled has a relationship with financing risk. The results show a positive and significant relationship with bank credit risk in the period 1995-2008 in Tunisia. According to him, the most profitable bank is a bank that has a higher risk.

Risk financing schemes at Islamic banks are expected to generate high profitability along with risk. This study will try to analyze whether variations in bad credit will increase or decrease profitability in Islamic banks.

Hypothesis 2 Regulation capital has a positive effect on NPF musharakah.

Several studies reveal that capital regulations have a positive relationship to credit risk of Islamic banking (Waemustafa and Sukri, 2015; Ahmad and Ahmad, 2004; Rahman and Shahimi, 2010). In contrast to Al-Wesabi and Ahmad (2013) who found a not significant positive relationship to credit risk in the GCC country. This research is based on the assumption that Islamic banks rely on capital regulations to absorb financing risks.

Hypothesis 3 Total musharakah financing has a positive effect on NPF musharakah.

In the previous literature, the use of variable amounts of musharakah financing to detect bank risk has not been found. Musharakah contract is one of the PLS schemes which has the highest risk among other contracts (Khan and Ahmed, 2001). A study has revealed that financing and profit and loss sharing (PLS) schemes have an impact on increasing problem financing in Indonesia (Abusharbeh, 2014). 
Hypothesis 4 Total financing has a positive effect on NPF musharakah.

Funding channeled to debtors is generally not risk free. The greater the amount of credit channeled will be the higher the risk of unpaid credit and the impact on the decline in credit quality (Funso, Kolade, and Oje, 2012; Waemustafa and Sukri, 2015). However, a selective attitude in channeling financing to potentially good sectors along with adequate management can affect the lower level of risk.

Hypothesis 5 Risk sector financing has a positive influence on NPF musharakah.

Loan portfolios at risk will result in higher NPLs (Berger and DeYoung, 1997). Several previous studies found that financing channeled to risky sectors became a problematic source of financing (Al-Smadi, 2010; Waemustafa and Sukri, 2015; Ahmad and Ariff, 2007; Ahmad and Ahmad, 2004). Different findings of Al-Wesabi and Ahmad (2013) reveal that the results do not affect the financing of risky sectors with credit risk in the GCC country.

Hypothesis 6 The inflation rate has a positive influence on NPF musharakah.

Inflation is an element of market risk because it causes movement in market conditions at a macro level, and its impact tends to spread in all directions, including the real sector financed by banks (Siregar, 2016). High inflation adversely affects Islamic bank financing in Malaysia (Waemustafa and Sukri, 2015). Statistically, inflation increases financing risks because inflation can weaken partners' ability to meet their obligations through the erosion of their real income (Al-Smadi, 2010). Some previous research uses inflation to measure exposure to financing risks and the results vary (Al-Wesabi and Ahmad, 2013; Abid, Quertani and Ghorbel, 2013; Castro, 2012).

Hypothesis 7 GDP growth has a negative influence on NPF musharakah.

In general, the theory shows that when the GDP growth rate increases it will increase economic activity (Samuelson, 2001). Smooth credit payments are also influenced by the level of income of the community. The higher the level of income of the people reflected in GDP, the likelihood of bad loans getting smaller. Previous research (Louzis, Vouldis, and Metaxas, 2011; Kabir, Worthington, and Gupta, 2015; Al-Wesabi and Ahmad, 2013) found similar results that GDP as a source that contributes to the level of bad credit.

\section{Research Method}

This research uses quantitative methods with panel data. Financial report data in quarterly form from 2012.1 to 2017.4. This study looks at seven independent variables, namely five variables related to internal banks, and two external variables. The dependent variable is the risk of musharakah financing for NPF sharia commercial banks. The variables examined in this study are presented in table 1.

\section{Sample and Data}

As many as 13 commercial Islamic banks in Indonesia. Some banks are inconsistent in publishing their financial statements and displaying extreme values of certain variable indicators so we apply the concept of anticipation of vision. We chose a bank based on purposive sampling. First, we choose Islamic commercial banks (ICB) that are registered with Bank Indonesia from 2008-2018. Second, we choose ICB which publishes annual financial reports and complete quarterly data consistently. Financial data is obtained from Bank Indonesia, the Financial Services Authority, and on the website of each ICB. We finally got data from 7 banks that consistently met the criteria, namely Bank Muamalat Indonesia, Mandiri Islamic Bank, BRI Syariah Bank, Panin Dubai Syariah Bank, BCA Syariah, Bank BNI Syariah, Bukopin Islamic Bank. The data used in this study is quarterly data for the period 2012 to 2017. 
Table 1. Description of variables

\begin{tabular}{|c|c|c|c|}
\hline Variables & Definition and measure & Source & Expected sign \\
\hline \multicolumn{4}{|l|}{ Dependent } \\
\hline NPF musharakah & $\begin{array}{l}\text { Non-performing finance of musharakah. } \\
\text { (Ratio of bad musharakah financing to } \\
\text { total musharakah financing) }\end{array}$ & $\begin{array}{l}\text { Srairi (2013); Waemustafa dan } \\
\text { Sukri (2015) }\end{array}$ & \\
\hline \multicolumn{4}{|l|}{ Independent } \\
\hline ROM & $\begin{array}{l}\text { Return on musharakah } \\
\text { (Yield of musharakah to total } \\
\text { musharakah financing) }\end{array}$ & Original & + \\
\hline REGCAP & $\begin{array}{l}\text { Regulatory capital } \\
\text { (Tier } 1 \text { (core capital) to total assets) }\end{array}$ & Waemustafa dan Sukri (2015) & + \\
\hline MUSFIN & $\begin{array}{l}\text { Musharakah financing } \\
\text { (Ratio of musharakah financing to total } \\
\text { financing) }\end{array}$ & Original & + \\
\hline FIN & $\begin{array}{l}\text { Total Financing } \\
\text { (Natural logarithm of total financing) }\end{array}$ & Waemustafa dan Sukri (2015) & + \\
\hline RSF & $\begin{array}{l}\text { Risky sector of financing } \\
\text { (Ratio of trade financing to total } \\
\text { musharakah financing) }\end{array}$ & $\begin{array}{l}\text { Al-Smadi (2010); Al-Wesabi } \\
\text { dan Ahmad (2013) } \\
\text { Waemustafa dan Sukri (2015) }\end{array}$ & + \\
\hline INF & Inflation rate, in percentage & $\begin{array}{l}\text { Waemustafa dan Sukri (2015); } \\
\text { Abid, Quertani \& Ghorbel } \\
\text { (2013). }\end{array}$ & + \\
\hline GDP Growth & $\left(G P_{t}-G D P_{t-1}\right) / G P_{t-1}$ & $\begin{array}{l}\text { Waemustafa dan Sukri (2015); } \\
\text { Al-Wesabi dan Ahmad (2013) }\end{array}$ & - \\
\hline
\end{tabular}

Source: Several Studies

\section{Method}

This study uses panel data with cross-sections of different sizes causing variance of errors between individuals is not constant or indicates heteroscedasticity. Generalized Least Square (GLS) provides a solution to overcome heteroscedasticity, which is one form of least square estimation. Based on the chosen model and the nature of heteroscedasticity, the procedure to be selected is the Cross-section Seemingly Uncorrelated Regression / SUR (Verbeek, 2000; Gujarati and Porter, 2015).

$$
\mathbf{N P F}_{\mathrm{it}}=\alpha+\beta_{1}(\mathrm{ROM})+\beta_{2}(R E G C A P)+\beta_{3}(M U S F I N)+\beta_{4}(\mathrm{FIN})+\beta_{5}(\mathrm{RSF})+B_{6}(I N F)+B_{7}(G D P G)+\varepsilon_{\mathrm{it}}
$$

We conduct regression on seven independent variables $\left(\beta_{1}, \beta_{2}, \ldots \beta_{7}\right)$ as estimation parameters. The $\varepsilon$ is an error term. Risk of musharakah financing is proxied by non-performing financing (NPF). Musharakah yields (ROM), regulatory capital (Regcap), total financing musharakah (MUSFIN), total financing (FIN), and risk sector financing (RSF) are internal bank variables. While the inflation (INF) and GDP growth (GDPG) are external variables. 
Table 2. Correlation Matrix

\begin{tabular}{lllllllll}
\hline Variable & NPF & ROM & REGCAP & MUSFIN & FIN & RSF & INF & GDPG \\
\hline NPF & 1 & & & & & & & \\
ROM & .222 & 1 & & & & & & \\
REGCAP & -.564 & -.127 & 1 & & & & & \\
MUSFIN & -.145 & -.095 & .309 & 1 & -.372 & 1 & & \\
FIN & .534 & .060 & -.715 & -.217 & .363 & 1 & & \\
RSF & .672 & .325 & -.501 & -.121 & .133 & .066 & 1 & \\
INF & .021 & .065 & -.004 & .121 & & & \\
DGPG & -.178 & -.136 & .108 & -.179 & -.226 & -.227 & -.583 & 1 \\
\hline
\end{tabular}

Source: Data processed

Table 2 shows the variable coefficients not correlating with other variables. The correlation coefficient does not exceed 0.8 , which indicates the absence of multicollinearity. Thus the regression in this study is free from multicollinearity.

The assumptions that must be met in the EGLS panel method are normality and non-multicollinearity, because the EGLS panel is able to accommodate the problems of autocorrelation and heteroscedasticity in the model (Verbeek, 2000; Gujarati and Porter, 2015). Jarque-Bera probability value $0.361174>0.05$ indicates residual normality and VIF value $<10$ in the multicollinearity test shows there is no correlation between the independent variables.

\section{Results and Discussion}

Table 3 presents a summary of descriptive statistics for internal and external variables used in this study. The average problematic financing for sharia commercial banks is $3.97 \%$, which indicates that the risk of musharakah financing is still relatively high in the 2012-2017 period. These results support the research of Khan and Ahmed (2001) who stated that high-risk funding was established in the musharakah financing agreement in Islamic banking.

Descriptive statistics for the average yield of ICBs in Indonesia are around 4.36\%, followed by an average capital regulation of around $11.39 \%$, which shows the average core capital of ICB's total assets in Indonesia. The portion of musharakah financing (MUSFIN) for each sharia commercial bank reaches 33.43\%, which indicates that only one third of musharakah financing comes from the total funds channeled by ICB, in other words, ICB financing is dominated by non-PLS financing. The low financing of musharakah provides evidence that funding the profit sharing scheme is a phenomenon of each country, this confirms that the contract has a high level of risk, so it is still largely avoided by banks.

Then, the total amount of financing (FIN) of each sharia commercial bank is 2,318,137 Billion Rupiah. Risk sector financing (RSF) illustrates the average portion of financing in the trade, restaurant and hotel sectors. This type of financing is channeled to $24.18 \%$ in the musharakah contract. Meanwhile, the average inflation (INF) is IDR 5,23\% and GDP growth refers to national economic growth which reached an average of 5.26\% in the period 2012-2017. 
Table 3. Descriptive statistic of bank panel data

\begin{tabular}{llllll}
\hline Variable & Mean & Std.Dev. & Max & Min & Obs. \\
\hline NPF & 3.972 & 1.691 & 7.120 & 1.360 & 168 \\
ROM & 4.363 & 2.761 & 11.171 & 0.014 & 168 \\
REGCAP & 11.388 & 6.336 & 44.020 & 4.990 & 168 \\
MUSFIN & 33.425 & 18.224 & 86.930 & 6.370 & 168 \\
FIN & 23.181 & 1.292 & 25.110 & 20.510 & 168 \\
RSF & 24.117 & 2.752 & 29.620 & 16.400 & 168 \\
INF & 5.238 & 1.768 & 8.400 & 3.020 & 168 \\
DGPG & 5.262 & 0.421 & 6.2100 & 4.740 & 168 \\
\hline
\end{tabular}

Source: Data processed

Following this, we present the regression results from the main factors that influence the risk of financing the Islamic commercial banks in Indonesia. Table 4 shows the EGLS estimation results with Cross-Section SUR.

Overall, the model shows that seven independent variables, four of which show coefficients that have a significant effect on financing risk. The MUSFIN, FIN, RSF and GDPG variable is significant at level 1\%. Variables ROM are significant at the 5\% level. Other variables, namely REGCAP, and INF are not significant. The R-squared value reveals that all independent variables explain $85.49 \%$ changes in the dependent variable.

This study found that during the study period, Musharakah Yield (ROM) shows a significant positive effect on the risk of musharakah financing. This finding is different from the initial hypothesis that musharakah yields have a negative effect on the risk of musharakah financing. However, this positive effect explains that although musharakah financing is considered risky and has a high NPF rate in the study period, banks still obtain a rate of return from restructured financing.

The total musharakah financing (MUSFIN) which has a positive and significant influence at the $5 \%$ level, indicates an increase in the amount of musharakah financing followed by an increase in risk at Islamic commercial banks in Indonesia. In line with the opinion of Khan and Ahmed (2001) which states that musharakah financing is the most risky contract among other contracts. Similarly, the findings of Abusharbeh (2014) concluded that increasing PLS financing was in line with the increased risk of financing in Indonesia. However, on the other hand, most of the musharakah financing is the success in implementing a revenue sharing scheme (PLS), which is an icon of Islamic banking.

Total financing (FIN) has a negative and significant effect on the risk of musharakah financing. This shows that the overall distribution of funds has shown a gradual increase. Every increase in the total financing of sharia commercial banks is predicted to reduce the risk of financing (NPF). Consistent with the findings of Farook et al. (2014) and Misman (2012) stated that the increase in total financing was related to a decrease in the level of problematic financing. The increase in total financing means that it does not have to lead to an increase in financing risk if appropriate management and financing policies accompany financing activities. Bank Indonesia (2016) also stated that overall funding has slowly improved. Although certain contracts (musharakah contracts) still show a positive influence on the financing problem. This finding was supported by $\mathrm{Wu}$, Chang, and Selvili (2003) who found that total financing was negatively related to credit risk.

Risk Sector Financing (RSF) had a significant positive effect on the risk of musharakah financing. The same thing was established by Waemustafa and Sukri (2015); Al-Wesabi and Ahmad (2013), who concluded that an increase in RSF was predicted to increase the risk of musharakah financing (NPF). Islamic public banks are vulnerable to the impact of risky sector financing, where the trade sector is considered the most risky. The trade sector is very sensitive to changes in economic conditions so that changes in economic conditions have an impact on increasing financing risk. Funding high-risk business activities tends to result in higher financing risks. 
External factors that influence financing risk are GDP growth. GDP growth (GDPG) has a significant negative effect on the risk of musharakah financing for sharia commercial banks. This result is consistent with the findings of the Al-Wesabi and Ahmad study (2013); Farook, Hasan, and Clinch (2014); Salas and Saurina (2002). The above line shows that when the national economy is conducive, which is characterized by GDP growth, the level of problematic financing also falls and is a positive signal for Islamic banking.

Table 4. Panel EGLS- Cross-section SUR

\begin{tabular}{cccc}
\hline Independent Variable & Coeff. & t-Stat & Prob. \\
\hline C & 20.45663 & 5.072556 & 0.0000 \\
ROM & $0.0414^{* * *}$ & 2.713557 & $\mathbf{0 . 0 0 7 4}$ \\
RECAP & 0.004841 & 0.484893 & 0.6284 \\
FIN & $0.0233^{* * *}$ & 5.879709 & $\mathbf{0 . 0 0 0 0}$ \\
RSF & $-0.7885^{* * *}$ & -5.201354 & $\mathbf{0 . 0 0 0 0}$ \\
INF & $0.2028^{* * *}$ & 9.785760 & $\mathbf{0 . 0 0 0 0}$ \\
GDPG & -0.044366 & -1.903913 & 0.0588 \\
R-squared & $-0.7374 * * *$ & -5.251141 & $\mathbf{0 . 0 0 0 0}$ \\
Adj. R-squared & 0.8549 & & \\
Durbin-Watson & 0.8426 & & \\
F. Statistic & 1.0749 & & \\
Log Likelihood & 69.797 & & \\
No.of observation & -189.45 & & \\
Chow test & 168 & & \\
\hline & 0.0000 & & \\
\hline
\end{tabular}

Source: Data processed

Notes: $* * *, * *$, and $*$ are signs of significance level of $1 \%, 5 \%$, and $10 \%$ consecutively.

Furthermore, regulation capital (REGCAP) has no effect related to the risk of musharakah financing. The same finding by Al-Wesabi and Ahmad (2013) states that regulation capital does not affect the credit risk of Islamic banks in the Gulf Cooperation Council or GCC countries. This illustrates that Islamic commercial banks not only absorb risk through capital reserves, but banks adhere to the principle of risk sharing. Likewise, the inflation rate does not affect this study, the negative coefficients produced are different from the hypothesis proposed in this study. This illustrates that the inflation rate during the study period did not increase significantly so that it did not have a negative impact on the risk of Islamic bank financing.

\section{F test (Simultaneous)}

The calculated F-value is higher than value of F-table. Hypothesis decisions, are independent variables simultaneously affecting the risk of musharakah financing (NPF Musharakah) as shown in table 5. 
Table 5. F Test (Simultaneous) the seven effect of independent variables to NPF musharakah

\begin{tabular}{llllll}
\hline F count & Ftabel & Prob. F & $\boldsymbol{\alpha}$ & Decision & Conclusion \\
\hline 69.797 & 2,067 & 0,000 & 0,05 & Reject Ho & Significant \\
\hline
\end{tabular}

Source: Data processed

Overall, these results present relevant empirical evidence in explaining the risk of musharakah financing. These results explain that if the portion of musharakah contract financing in the risky economic sectors, namely the trade, hotel and restaurant sector has increased, then the risk of financing will increase as well. In line with previous research which states the quality of financing decreases with increasing financing in risk sectors (Waemustafa and Sukri, 2015; Al-Smadi, 2010). Therefore, Islamic banks must make a mapping of economic sectors that do not have high risk but have good business prospects.

On the other hand, the total financing of all contracts can have an impact on reducing the amount of problem financing. Islamic commercial bank financing is dominated by murabahah contracts that have low risk and also other non-PLS financing (Bank Indonesia, 2016). The previous financing concept assumes that the amount of financing disbursed will be directly proportional to risk. The results of previous studies found a similar effect, as in the findings of Ali and Ghauri (2013). One form of caution of Islamic commercial banks in Indonesia in managing financing is to enable the use of collateral from partners, both in the form of movable and immovable objects submitted by the collateral owner to Islamic Banks, to guarantee repayment of partner obligations (Law of the Republic of Indonesia Number 21 2008) concerning Islamic Banking. This is in line with the statement of Mohamad, et al., (2014), that in real transactions such as investment, sales and rent, banks need a risk management effort to prevent excessive risk.

Thus, a country's GDP growth continues to contribute to financing risk. this finding is supported by Al-Wesabi and Ahmad (2013) and Jimenez and Saurina (2005) that an increase in GDP growth illustrates the ability of partners to pay off financing. so the rate of return on financing is largely determined by the level of income of the community / partners.

Finally, our empirical results detect the risk of musharakah financing in Islamic banks, which can be seen from internal factors (yields, total musharakah financing, total financing of all contracts, risk sector financing) and external factors (GDP growth). In addition, this research model can also be applied to other financial institutions that apply sharia principles. Thus, the quality of financing can be maintained and the risks can be minimized properly in the future.

\section{Conclusion}

The PLS scheme is a major feature of Islamic banks and ideally dominates Islamic bank financing schemes. Musharakah is a PLS financing scheme that is popularly applied to Islamic bank operations compared to mudharabah, both in Indonesia and in other countries. However, musharakah has the highest risk, so this study tries to investigate the internal and external factors of banks which are the causes of the high risk of Islamic banks musharakah financing.

The results of empirical studies find that internal factors (i.e., ROM, MUSFIN, RSF, FIN) and external factors (i.e., GDP growth) significantly influence the risk level of musharakah financing. ROM, MUSFIN and RSF variables have a positive effect on the risk level of musharakah financing. The FIN and GDP growth variables negatively affect the risk level of musharakah financing. Meanwhile, we found that REGCAP and INF had no significant effect on the risk of musharakah financing.

This finding has practical implications for banks to consider several internal and external factors in anticipation of higher non-performing financing in the musharakah contract in the future. This study has limitations as it does not consider qualitative aspects. Despite the urgency of this quantitative study of ICB musharakah financing risk, we recommend that a qualitative study be carried out to supplement the quantitative explanation regarding risk factors for musharakah financing. 


\section{Acknowledgements}

The author would like to thank the Ministry of Research, Technology and Higher Education for supporting this research.

\section{References}

Abedifar, P., Molyneux, P., \& Tarazi, A. (2013). Risk in Islamic Banking. Rev. Financ. 17, 2035-2096.

Abusharbeh. (2014). Credit risk and profitability of islamic bank: evidence from Indonesia. World Review of Business Research, 4(3) 136-147.

Ahmad, N.H. \& Ahmad, S.Nizam. (2004). Key Factors Influencing Credit Risk Of Islamic Bank: A Malaysian Case. Proceedings of The National Seminars In Islamic Banking \& Finance (IBAF). Malaysia: Intel Multimedia And Publications.

Ahmad, N., Ariff, M. (2007). Multi-country study of Bank Credit Risk determinants, International Journal of Banking and Finance, 5 (1), 135-152.

Ahmed, N., Ahtar, MF, \& Usman, M. (2011). Risk management practices and Islamic banks: Empirical investigations from Pakistan. Jurnal Penelitian Interdisipliner di Indonesia Bisnis, 1 (6), 50-57.

Antonio, M.S. (2001). Islamic Banks: From Theory to Practices. Edition 1. Jakarta.

Ali, A. \& Ghauri, S. P. (2013). Global crisis and credit risk management by banks: A comparative study of banks in Pakistan. International Journal of Business and Economics Research, 2(6): 158-168.

Al-Wesabi, H. A. H., \& Ahmad, N. H. (2013). Credit risk of Islamic banks in GCC countries. International Journal Banking and Finance. Vol.10(2), Artikel 8.

Al-Smadi, M. O. M. (2010). Credit Risk, Macroeconomic and Bank Specific Factors in Jordanian Banks. PhD Thesis, Universiti Utara Malaysia.

Amuakwa-Mensah, F., Marbuah, G., \& Ani-Asamoah, D.M. (2015). Re-examining the Determinants of NonPerforming Loans in Ghana's Banking Industry: Role of the 2007-2009 Financial Crisis. Journal of African Business. 1522-9076.

Apergis, N. (2014). The long-term role of non-traditional banking in profitability and risk profiles: Evidence from a panel of US Banking Institutions. Journal of International Money and Finance 45, 61-73.

Ascarya, D. Yumanita. (2006). Akad dan Produk Bank Islam: Konsep dan Praktek di Beberapa Negara . Bank Indonesia.

Ascarya, D. Yumanita. (2009). Dual Financial System Stability Formulation in Indonesia. Bank Indonesia: Working Paper Series 11/2009, November 2009. Jakarta: Pusat Pendidikan dan Studi Kebanksentralan, Bank Indonesia.

Atanasijevic, J., \& Bozovic, M. (2016). Exchange rate as a determinant of corporate loan defaults in a Euroized economy: Evidence from micro-level data. Eastern European Economics, 54, 228-250.

Athanasoglou, P.P., Brissimis, S.N., Delis, M.D. (2008). Bank-specific, industry-specific and macroeconomic determinants of bank profitability. Journal of International Financial Markets, Institutions and Money 18, 121-136.

Bank Indonesia. (2012). Financial System Stability, What, Why, and How? Bank Indonesia: Jakarta.

Bank Indonesia. (2016). Indonesian Islamic Banking Statistics. Jakarta.

Financial Services Authority. (2013). Islamic Banking Statistic. Indonesia.

Bank for International Settlement. (2000). Principles for the management of credit risk. Basel

Baele, L., Farooq, M,. \& Ongena, S. (2010). "Of religion and redemption: evidence from default on Islamic loans”, Working Paper.

Berger, A. N. \& DeYoung, R. (1997). "Problem Loans and Cost Efficiency in Commercial Banks". Journal of Banking and Finance, $21.849-870$.

Chaibi, H \& Ftiti, Z. (2015) Credit risk determinants: Evidence from a cross-country study. Research in International Business and Finance, 33. 1-16.

Castro, V., (2013). Macroeconomic determinants of the credit risk in the banking system: The case of the GIPSI. Econ. Model Working Paper, 31. 672-683.

Chapra, M. U. \& Khan, T. (2000). Regulation and supervision of Islamic banks. Jeddah: Islamic Development Bank-Islamic Research and Training Institute.

Chong, B. S., \& Liu, M.-H. (2009). Islamic banking: Interest-free or interest-based? Pacific-Basin Finance Journal, 17(1), 125144.

Errico, L. \& Farrahbaksh, M., (1998). "Islamic banking: Issues in prudential regulation and supervision". IMF Working Paper 98/30.

Dietrich, A., Wanzenried, G. (2011). Determinants of bank profitability before and during the

crisis: Evidence from Switzerland. Journal of International Financial Markets, Institutions and Money 21, $307-327$.

Farook, S., Hassan, M. K., \& Clinch, G. (2014). Islamic bank incentives and discretionary loan loss provisions. Pacific-Basin Finance Journal, 28, 152-174.

Funso, K.T., Kolade A.R., and Ojo O.M. (2012). Credit Risk and Commercial Bank's Ferformance in Nigeria: A Panel Model Approach. Australian Journal of Business and Management Research, 2(2), 31-38. 
Fleifel, B. A. (2009). Risk management in Islamic banking and finance: The Arab finance house example. An unpublished thesis submitted to the University of North Carolina Wilmington, USA.

Gujarati, D. N. (1995). Basic Econometrics. Third Edition, McGraw-Hill Publisher.

Gujarati, D.N \& Porter, D.C. (2015). Basic Econometrics. Fifth Edition, Book 2. Jakarta: Salemba Empat.

Hart, O., \& Moore, J. (1998). Default and Renegotiation: A Dynamic Model of Debt. Quarterly Journal of Economics, Vol. 113.

Irina, B., \& Angela, R. (2016). Effects of macroeconomic factors on bank loans quality: Evidence from Central and Eastern European countries. Entrepreneurship, Business and Economics, 2. 571-584.

Khan, T. \& Ahmed, H. (2001). Risk Management: An Analysis of Issues in Islamic Financial Industry. Jeddah: Islamic Development bank-Islamic Research and Training Institute.

Khemraj, T., \& Pasha, S. (2009). The determinants of non-performing loans: An econometric case study of Guyana. Paper presented at The Caribbean Centre for Banking and Finance Bi-Annual Conference on Banking and Finance, St. Augustine, Trinidad.

Khemraj, T., \& Pasha, S. (2016). Determinants of nonperforming loans in Guyana. In A. V. Gevorkyan \& O. Canuto (Eds.), Financial deepening and post-crisis development in emerging markets (pp. 169-187). New York: Palgrave Macmillan US.

Louzis, Dimitrios P., A.T. Vouldis, \& V.L. Metaxas. (2012). Macroeconomic and Bank-specific Determinants of Nonperforming Loans in Greece: A Comparative Study of Mortgage, Business, and Consumer Loan Portfolios. Bank of Greece Working Paper 118 (Athens: Bank of Greece).

Messai, A.S., \& Jouini, F. (2013). Micro and Macro Determinants of Non-performing Loans. International Journal of Economics and Financial Issues. 3(4). 852-860.

Mohamad, S., Othman, J., Roslin, R., \& Lehner, O.M. (2014). The use of Islamic instrument as non-speculative risk management tools. Venture Capital: An International Journal of EntrepreneurialFinance, 16:3, 207-226.

Mills, P. S. \& Presley, J.R. (1999). "Islamic finance: Theory and practice”, Macmillan, London.

Misra, B.M. \& Sarat Dhal. (2010). "Pro-cyclical management of non-performing loans by the Indian public sector banks". BIS Asian Research Papers, Juni.

Misman. (2012). Financing structure, bank specific variabel and credit risk: Malaysian islamic banks. Journal of Business and Policy Research, 7(1). 102-114

Nachrowi, D. Nachrowi. (2006). Pendekatan Populer dan Praktis Ekonometrika untuk Analisis Ekonomi dan Keuangan. Jakarta: Fakultas Ekonomi UI.

Nkusu, M. (2011). Non-performing loans and macrofinancial vulnerabilities in Advanced Economies, IMF Working Paper $11 / 161$

Rahman, A.A. \& Shahimi, S. (2010). Credit Risk and Financing Structure of Malaysian Islamic Banks. Journal of Economic Cooperation and Development, 31(3). 83-105.

Rajesh, K.A, \& Yousef, T. (2000). Islamic Bank and Investment Financing. Journal of Money, Credit and Banking. Vol.32, No.1

Ramasamy, et al., (2011). Relative Risk Of Islamic Sukuk Over Government And Conventional Bonds. Global Journal of Management and Business Research, Vol.11, 6.

Reinhart, C., \& Rogoff, K., (2010). From financial crash to debt crisis. NBER Working Paper 15795.

Salas, V., \& Saurina, J., (2002). Credit risk in two institutional regimes: Spanish commercial and savings banks. Journal Financ Service Research, 22. 203-224.

Samuelson, P.A., \& Nordhaus, W.D. (2001). Macroeconomics. Jakarta PT. Media Edukasi.

Sundararajan V, \& Errico, L. (2002). "Islamic Financial Institutions and Products in the Global Financial System: Key Issues in Risk Management and Challenges Ahead", IMF Working Paper No. WP/02/192, International Monetary Fund,Washington, DC.

Srairi, S. (2013). Ownership structure and risk-taking behaviour in conventional and Islamic banks: Evidence for MENA countries. Borsa Istanbul Review 13 (2013) $115 \mathrm{e} 127$.

Stiglitz, J. E. (1974). Incentives and Risk Sharing in Sharecropping. National Science Foundation and Ford Foundation. Yale University.

Verbeek, M. (2000). A Guide to Modern Econometrics. New York: Wiley.

Waemustafa, W., \& Sukri, S. (2015). Bank Specific and Macroeconomics Dynamic Determinants of Credit Risk in Islamic Banks and Conventional Banks. International Journal of Economic and Financial Issue, 5(2), 476-481.

Warninda, T.W., Ekaputra, I.A., \& Rokhim, R. (2019). Do Mudarabah and Musharakah financing impact Islamic Bank credit risk differently? Research in International Business and Finance, 49, 166-175.

Wu, W.C., Chang, C.O., \& Selvili, Z. (2003). Banking System, Real Estate Markets, and Nonperforming Loans.

Yurdakul, F. (2014). Macroeconomic modeling of credit risk for banks. Procedia of Social and Behavioral Science. $784-793$.

Zribi, N., \& Boujelbène, Y. (2011). The factors influencing bank credit risk: the case of Tunisia. Journal of Accounting and Taxation Vol.3(4), 70-78.

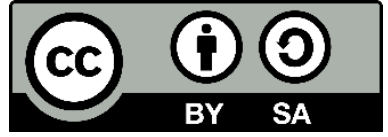

(C) 2020 by the authors. Licensee ACRN Publishing, Austria, Editor in Chief Prof. Dr. Othmar M. Lehner. This article is an open access article distributed under the terms and conditions of the Creative Commons Attribution (CC BY SA) license (https://creativecommons.org/licenses/by-sa/4.0/) 